Anhelina UHGRIN ${ }^{1}$, Henrietta BÁN ${ }^{2}$

Opiekun naukowy: Vitaly GERASIMOV ${ }^{3}$, Alexander MOLNAR ${ }^{4}$

DOI: https://doi.org/10.53052/9788366249837.37

\title{
DODATKOWY NATURALNY SYSTEM OGRZEWANIA DOMU
}

Streszczenie W artykule opisano rozwój systemu pozyskującego ciepło z przestrzeni poddasza domu. Potwierdzono, że taka energia cieplna może być używana do częściowego ogrzewania wewnętrznej przestrzeni domu. Zaproponowany system jest sterowany za pomocą mikrokontrolera wykorzystującego czujniki temperatury oraz przewody wentylacyjne zainstalowane w stropach budynku.

Słowa kluczowe: ogrzewanie, czujniki, mikrokontrolery

\section{ADDITIONAL NATURAL HEATING SYSTEM OF HOUSE}

Summary This paper presents the results of the development of a system for using heat from the attic space of the house. It has been established that this heat energy can be used for partial heating of the interior space of the house. The proposed system is controlled by a microcontroller system using a temperature sensors and flow ducts installed in the ceiling of the house.

Keywords: heating, roof, house, sensors, microcontroller.

\section{Introduction}

The problem of home heating is currently receiving a lot of attention. The price of fossil energy sources has increased significantly in recent years and continues to rise.

1 Mukachevo State University, Faculty of Economics, Management and Engineering, ugrinangelina801@gmail.com

${ }^{2}$ Uzhhorod National University, Ukrainian-Hungarian Educational Institute, Department of Physics and Mathematics, specjalność: Physics, galdavidagu7@gmail.com

${ }^{3}$ Ph.D. Mukachevo State University, Faculty of Economics, Management and Engineering, vitgerv@gmail.com

${ }^{4}$ Dr., Prof., Uzhhorod National University, Department of the Physics of Semiconductors, alex.molnar@uzhnu.edu.ua 
Therefore, the problem of finding alternative and affordable home heating systems is an urgent problem for today $[1,2,3]$.

\section{Implementation}

The authors noted that by additional heating of the house, natural heat can be used, which is accumulated in the attic of the house due to direct heating of the roof by solar light radiation [4]. The proposed technique makes it possible to additionally heat the living quarters of the house due to the controlled redirection of the airflow from the upper structure of the house to the lower ones. Eventually, this technique is effective only at certain times of the year - in spring and early summer. This period is characterized by the thermal activity of the sun at a relatively low ambient temperature. The latter gives the effect of an uncomfortable stay in the house. The proposed heat redirection system is active and based on an automated monitoring and control system implemented through air temperature and airflow sensors (Fig.1).

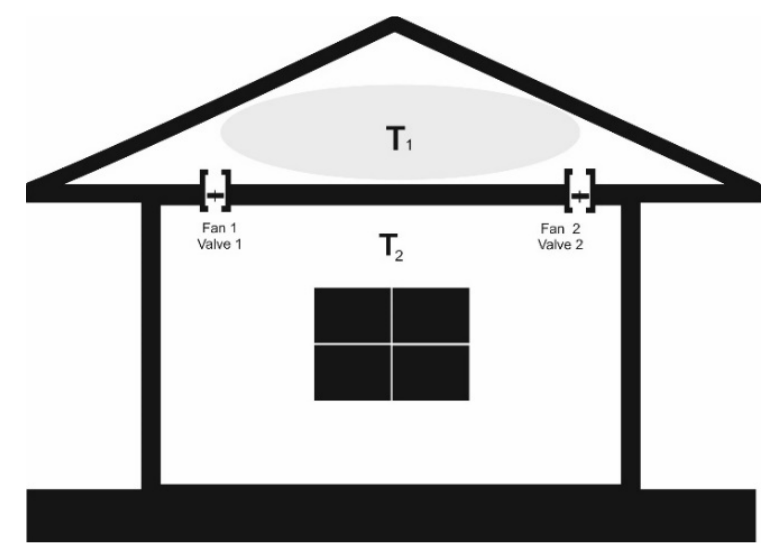

Figure 1. Diagram of the organization of air circulation from the attic to the interior of the house.

The implementation of this project is planned to be realized through the control modules of the Texas Instruments company, namely based on the MSP430 [5]. Indication of the state of the main parameters of the device is displayed on the LCD display module. These modules are similar to the Arduino system, and may well be implemented on their basis as well. Technically, the structure consists of two air vents mounted in the ceiling of the upper floor of the room, which in turn open into the attic space of the house. The first ductworks to bring warm air into the room, and the second to pull it back into the attic. Thus, the air circulation system is looped.

For a specific implementation, the project should take into account several points. The first of them is forced air circulation through the use of electric air fans. Without them, air circulation will naturally be slow and the effect of using the entire design is minimal. The second point is the inclusion of air filters in the circuit, especially in the inlet part of the duct (first duct). This is because that the air in the attic is very dusty, and its further ingress into the living space is very undesirable. And finally, the third point is the use of valves in the duct system. Since the use of this system is episodic, 
the use of a closing valve will make it possible to mechanically disconnect the ventilation system from functioning.

The control of the entire system is planned to be assigned to a microcontroller module, which, according to signals from sensors, will control the operation of the intake and exhaust fans. The main monitoring parameter will be the temperature differential between the room and the attic - the larger it is, the more speed (or time) the flow fans will turn on. The use of an intelligent system for monitoring and controlling fans can reduce the noise level from their work, as well as reduce the level of energy consumption in general. Also, an additional parameter that improves the efficiency of this system will be the inclusion of airflow sensors. The use of the latter will lead to better performance of the system but will naturally lead to the greater complexity of the design of the system. The generalized algorithm of air circulation system operation is presented in Fig. 2.

In addition to the above, taking into account the area (volume) of the attic space, as well as, the interior space can increase the operation of the entire system. The higher the indicators for the upper room and the smaller it is for the lower one the more efficient the work of the proposed system becomes. The use of galvanized iron as a roofing material leads to better and higher heating of the space.

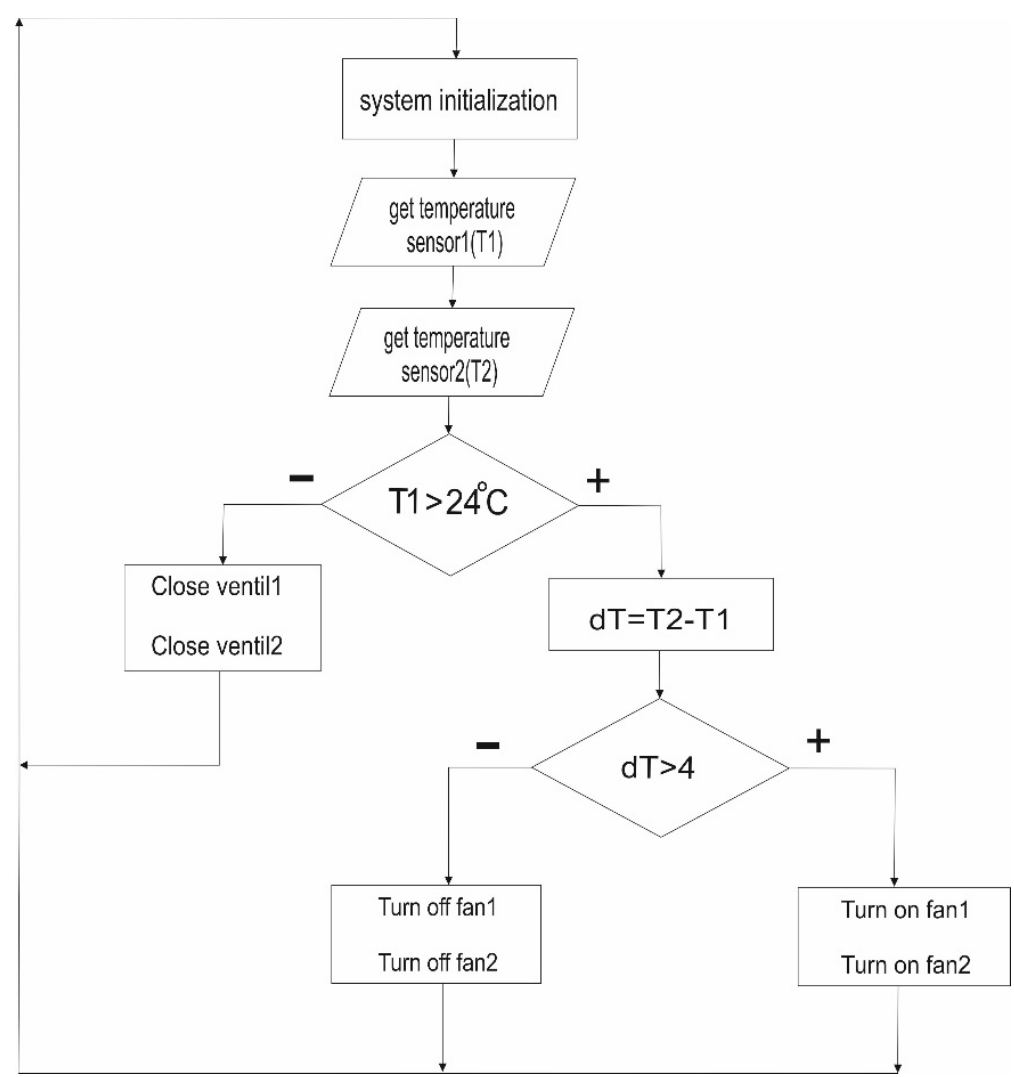

Figure 2. Generalized algorithm of air circulation system operation. 


\section{Hardware and Software implementation}

The implementation of this project involves the use of microcontroller modules from Texas Instruments.

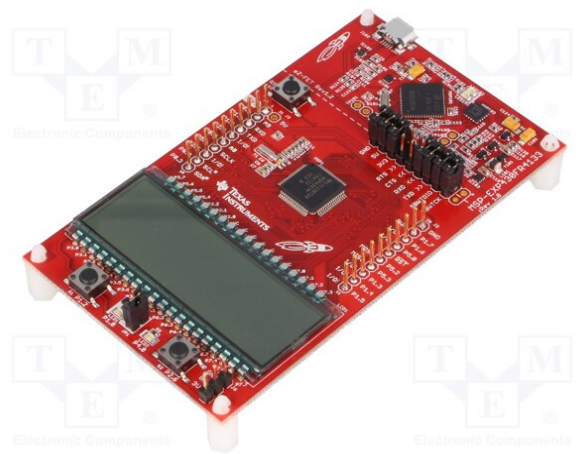

Figure 3. Example of using a ready-made microcontroller module a TI with LCD display.

This company allows you to use specialized modules on an available component base. First of all, these are the products of the CapTIvate and Ultrasonic Sensing Design line. CapTIvate Design Center's specialized software is designed to develop applications with touch devices based on CapTIvate microcontrollers. With this tool, you can configure the CapTIvate module in graphical mode and start working on a project containing touch controls as soon as possible.

Similar Ultrasonic Sensing Design Center software has been developed for Ultrasonic Sensing microcontrollers. In addition to the module configuration utility in graphical mode, this software package contains many ready-made libraries with examples of their application.

The software development tools, which were used to develop, include Code Composer Studio (with unlimited possibilities and a huge library of ready to use solutions), IDE Energia integrated development environment for Arduino compatible developments [6] or MSPWare-Advanced system. To improve energy efficiency, we used separate optimizers such as EnergyTrace software.

\section{Conclusion and summary}

Thus, modern houses use more and more technologically advanced materials, and the space under the metal roofing from which the roofs of houses are usually composed, are exposed to strong heating under the influence of direct sunlight. Using this heat to create comfortable life support in the house and free of charge is an alternative to expensive gas or a fireplace, which ultimately leads to the preservation of the environment and the budget of the residents. 


\section{REFERENCES}

1. ZAUGG A.: The Complete Handbook of Solar Air Heating Systems. Knowledge Publications. 2009.

2. TYMKOW P., TASSOU S., KOLOKOTRONI M., JOUHARA. H.: Building Services Design for Energy Efficient Buildings. Routledge. 2020.

3. ATHIENITIS AK.: Thermal Analysis and Design of Passive Solar Buildings (Best (Buildings Energy and Solar Technology)). Routledge. 2020.

4. GEVORKIAN P.: Alternative Energy Systems in Building Design. McGrawHill Education. 2009.

5. JIMÉNEZ M., PALOMERA R., COUVERTIER I.: Introduction to Embedded Systems: Using Microcontrollers and the MSP430. Springer, 2014.

6. Web: https://energia.nu/ 
